\title{
A comparison of the antibacterial activity of some African black soaps and medicated soaps commonly used for the treatment of bacteria-infected wound
}

\begin{tabular}{|c|c|}
\hline \multicolumn{2}{|c|}{$\begin{array}{l}\text { Authors: } \\
\text { Olufunmiso O. Olajuyigbe }{ }^{1} \\
\text { Morenike O. Adeoye-Isijola } \\
\text { Otunola Adedayo }{ }^{1}\end{array}$} \\
\hline \multicolumn{2}{|c|}{$\begin{array}{l}\text { Affiliations: } \\
{ }^{1} \text { Department of Microbio } \\
\text { School of Science and } \\
\text { Technology, Babcock } \\
\text { University, Nigeria }\end{array}$} \\
\hline \multicolumn{2}{|c|}{$\begin{array}{l}\text { Corresponding author: } \\
\text { Olufunmiso Olajuyigbe, } \\
\text { funmijuyigbe12@yahoo.com }\end{array}$} \\
\hline \multicolumn{2}{|c|}{$\begin{array}{l}\text { Dates: } \\
\text { Received: } 03 \text { Mar. } 2017 \\
\text { Accepted: } 20 \text { Aug. } 2017 \\
\text { Published: } 29 \text { Sept. } 2017\end{array}$} \\
\hline \multicolumn{2}{|c|}{$\begin{array}{l}\text { How to cite this article: } \\
\text { Olajuyigbe, O.O., Adeoye- } \\
\text { Isijola, M.O. \& Adedayo, O., } \\
\text { 2017, 'A comparison of the } \\
\text { antibacterial activity of some } \\
\text { African black soaps and } \\
\text { medicated soaps commonly } \\
\text { used for the treatment of } \\
\text { bacteria-infected wound', } \\
\text { Journal of Medicinal Plants } \\
\text { for Economic Development } \\
\text { 1(1), a20. https://doi.org/ } \\
\text { 10.4102/jomped.v1i1.20 }\end{array}$} \\
\hline \multicolumn{2}{|c|}{$\begin{array}{l}\text { Copyright: } \\
\text { ( ) 2017. The Authors. } \\
\text { Licensee: AOSIS. This wo } \\
\text { is licensed under the } \\
\text { Creative Commons } \\
\text { Attribution License. }\end{array}$} \\
\hline \multicolumn{2}{|l|}{ Read online: } \\
\hline 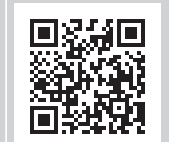 & $\begin{array}{l}\text { Scan this QR } \\
\text { code with your } \\
\text { smart phone or } \\
\text { mobile device } \\
\text { to read online. }\end{array}$ \\
\hline
\end{tabular}

Background: Black soap is a medicinal product that could be harnessed for economic purpose if properly packaged, and misconception about its traditional use by herbalists is thrown overboard.

Aims: To promote the relevance of these soaps for economic development, this study compared the antibacterial activity of black soaps with medicated soaps widely used against bacterial infections.

Methods: The antibacterial activities of these soap samples were determined by agar diffusion and macrobroth dilution methods.

Results: In this study, the statistical analysis of the inhibition zones showed that black soaps were significantly $(p<0.05)$ more active than medicated soaps used against the test bacterial isolates. The black soaps inhibited and killed the isolates better than the medicated soaps at the different concentrations used. The minimum inhibitory concentration for Klebsiella pneumoniae and Enterococcus faecalis ranged between $0.125 \mathrm{mg} / \mathrm{mL}$ and $2 \mathrm{mg} / \mathrm{mL}$, Staphylococcus aureus (0.25-4) $\mathrm{mg} / \mathrm{mL}$, Escherichia coli (0.125-4) $\mathrm{mg} / \mathrm{mL}$ and Pseudomonas aeruginosa (1-4) mg/mL. The result showed that K. pneumoniae and E. faecalis were the most susceptible, followed by $E$. faecalis $>$ E. coli $>$ S. aureus $>$ P. aeruginosa.

Conclusion: As a valuable medicinal output derivable from organic waste product that could be converted to wealth, African black soap production, utilisation and commercialisation have tremendous economic potentials. These soaps showed significant antibacterial activity greater than those of the medicated soaps. Hence, their use could be a better option in place of commercially available medicated and antiseptic soaps because of the degree of antibacterial activities they exhibited.

\section{Introduction}

Soap may be defined as a chemical compound resulting from the interaction of fatty acids, oils and salt (Friedman \& Wolf 1996). It is a cleaning agent made by the chemical action of alkali on fats or fatty acids to yield the sodium or potassium salts of these acids (Considine 1974). It possesses properties that may include wetting and emulsifying power, surface tension lowering and gel formation as well as acting as both active medication and vehicle for the incorporation of other active substances (Grayson 1983). In the treatment of skin diseases, it causes cooling, drying, hydration, crust and scale removal (Schwartz 1979). Although bacteria that attack human body are of great importance with reference to health, Fuls et al. (2008) reported the inhibitory potential of antimicrobial and non-antimicrobial soaps in clinical cases. Larson et al. (1987) and Toshima et al. (2001) indicated that soaps containing antimicrobial active ingredients could remove more bacteria as compared to plain soap, and Osborne and Grube (1982) had earlier reported that antibacterial containing soaps can remove $65 \%$ to $85 \%$ bacteria inhabiting human skin. When used properly, washing with soap could reduce Propiobacterium acnes and prevent secondary infections in acne skin (Kuehl et al. 2003) and healthcare-associated transmission of contagious diseases more effectively (Arya et al. 2005).

In ethnomedicine, described as total combination of knowledge, practice and belief incorporating plants, animals and minerals based medicine in diagnosing, preventing or eliminating a physical, mental or social disease and which may rely exclusively on past experience handed down from generation to generation either verbally or in writing (Sofowora 1982; Summers 2016), the use of soaps as vehicles for the application of medicinal plants for external use and in the treatment of skin diseases has been reported (Ahmed et al. 2005; Ajaiyeoba et al. 2003; Ajose 2007) because 
locally manufactured soaps have some antimicrobial properties (Adebiyi 1980; Lamikanra \& Allwood 1977; Moody et al. 2004). For centuries, the traditionally manufactured black soap, otherwise known as 'African black soap', has been used, in Ghana and Nigeria, to help relieve acne, oily skin, clear blemishes and various other skin issues. Black soap has been employed to get rid of skin rashes, ringworm, measles and body odours (Adelakun 1990) and for treating many infections caused by microorganisms as well as for exfoliating and deep cleansing (Underwood 2008). Although it is full of vitamins and emollients perfect for cleansing deeply, exfoliating gently and moisturising thoroughly, it is hypoallergenic and a great choice for those prone to skin rashes (Ukatta 1991). It also has the ability to emulsify grease and oil that hold dirty particles (Sharma 2006). Having antiseptic properties and being a natural shampoo to avoid dry itchy scalp, it is good for showering, bathing, washing hair and faces and helps keep the skin clear of premature facial lines.

In Africa, traditionally manufactured soap, otherwise known as African black soap, is known by different names from various regions. In Ghana, black soap is known as 'Anago soap' or 'Alata samina'. In Nigeria, it is known by the Hausas as 'Sabilum-salo', the Yorubas call it 'Ose-dudu' or 'abuwe' and the Igbos name it 'Ncha-Nkota' (Aliyu et al. 2012; Bella 2011; Getradeghana 2000; Summers 2016). African black soap is a natural source of vitamins $A$ and $E$ and iron (Grieve 1997). It is made of a combination of water, roasted plantain skin or cocoa pod, palm oil, palm kernel oil or shea butter. These are common oils used for the production of soap through saponification reactions (Kubmarawa \& Atiko 2000). Depending on where it is manufactured, black soap contains leaves and bark from plantains, shea tree, cocoa pods or palm tree leaves. The leaves and bark are sun dried before being roasted slowly in a pot after which different oils including coconut oil, shea butter and palm kernel oil giving antimicrobial properties to the soap are added to the mixture (Getradeghana 2000). The soap mixture is then allowed to cool for at least 2 weeks before it is ready for use. Black soap made with shea butter offers protection against UV rays, whereas black soap made with plantains contains a high concentration of iron along with vitamins $\mathrm{A}$ and $\mathrm{E}$ (Underwood 2008). Although the ingredients and process can change depending on the area, its methods of preparation have been passed down from generation to generation to keep the soap close to Mother Nature and avoid exploitation and imitation (Sofowora 1982; Summers 2016).

Although the active ingredients in most antibacterial soaps are often listed on the packaging, quantitatively, those of traditionally manufactured soaps are unknown. Consequently, the therapeutic potentials of these black soaps have become inconsequential, probably because of its manufacturing procedures, packaging and misconception about its use by the traditional herbalists and its being indigenous. However, because of its ethnotherapeutic applications in the treatment of skin infections, wounds and the daily intake of its lather solution mixed with other plant extracts for detoxification, it becomes essential to investigate its antibacterial activities in comparison with those of some medicated soap with antibacterial properties commonly sold. Hence, this study was aimed at comparing the antibacterial activity of black soap samples obtained from south-west Nigeria with three medicated soaps used worldwide against five selected bacterial isolates implicated in wound infections.

\section{Materials and methods Collection of samples}

Ten African black soap samples usually made from locally harvested and dried plant materials such as cocoa pods, plantain peels, palm tree leaves and shea butter tree bark were collected from 10 different towns in south-west Nigeria, whereas three antibacterial soaps, Dettol, Trichlorophenylmethyliodosalicyl (TCP) and Tetmosol, were purchased from a pharmacy outlet.

\section{Test microorganisms}

Five bacterial strains including Pseudomonas aeruginosa ATCC 19582, Staphylococcus aureus ATCC 6538, Escherichia coli ATCC 25922, Klebsiella pneumoniae ATCC 10031 and Enterococcus faecalis ATCC 19582 obtained from the Department of Biochemistry and Microbiology, University of Fort Hare, Alice, South Africa, were used for this study.

\section{Antibiotic susceptibility testing using agar diffusion method}

Each of the isolates was standardised using colony suspension method (EUCAST 2000). Each strain's suspension was matched with $0.5 \mathrm{McF}$ arland standards to give a resultant concentration of $1.0 \times 10^{6} \mathrm{cfu} / \mathrm{mL}$. The susceptibility of the different isolates to the different soap samples was determined using the modified Kirby-Bauer diffusion technique (Cheesbrough 2002) by swabbing the Mueller-Hinton agar (MHA) (Oxoids UK) plates with the resultant saline suspension of each strain. Wells were then bored into the agar medium with a heat sterilised 6-mm cork borer. The wells were filled with $100 \mu \mathrm{L}$ of different concentrations $(3.5 \mathrm{mg} / \mathrm{mL}$, $7.0 \mathrm{mg} / \mathrm{mL}, 14.0 \mathrm{mg} / \mathrm{mL}, 28.0 \mathrm{mg} / \mathrm{mL}$ and $32 \mathrm{mg} / \mathrm{mL}$ ) of each soap sample prepared taking care not to allow spillage of the solutions onto the surface of the agar. The plates were allowed to stand for at least $30 \mathrm{~min}$ before being incubated at $37^{\circ} \mathrm{C}$ for $24 \mathrm{~h}$ (BSAC 2013). The determinations were done in duplicate. After $24 \mathrm{~h}$ of incubation, the plates were examined for zones of inhibition (Bauer et al. 1996). The diameters of the inhibition zones produced by each soap sample were measured and interpreted using the CLSI zone diameter interpretative standards (CLSI 2015).

Minimum inhibitory concentrations (MICs) are important in diagnostic laboratories to confirm resistance of microorganisms to an antimicrobial agent and to monitor the activity of new antimicrobial agents. The susceptibility of the selected bacterial strains to each soap sample and their MICs were determined in duplicate by the standard macrobroth 
dilution method in Mueller-Hinton broth (CLSI 2002; Wiegand et al. 2008). To determine the MICs of each soap sample, different concentrations ranging from $0.5 \mathrm{mg} / \mathrm{mL}$ to $16 \mathrm{mg} / \mathrm{mL}$ were prepared by serial dilution in double strength Mueller-Hinton broth. The tubes were inoculated with $100 \mu \mathrm{L}$ of each of the bacterial strains. Blank MuellerHinton broth was used as negative control. The bacteriacontaining tubes were incubated at $37^{\circ} \mathrm{C}$ for $24 \mathrm{~h}$. Each assay was performed two times. The MIC was defined as the lowest soap concentrations that showed no growth in the MuellerHinton broth.

\section{Determination of minimum bactericidal concentrations}

The minimum bactericidal concentrations (MBC) assay was carried out as described by Cheesbrough (2006). Here, fresh nutrient agar plates were inoculated with one loopful of culture taken from each of the broth cultures that showed no growth in the MIC tubes. The plates were incubated at $37^{\circ} \mathrm{C}$ for $24 \mathrm{~h}$. After the incubation period, the lowest concentration of the extract that did not produce any bacterial growth on the solid medium was regarded as MBC values for these soap samples (Irkin \& Korukluoglu 2007). This observation was matched with the MIC test tube that did not show evidence of growth after $48 \mathrm{~h}$ of incubating the bacterial cultures.

\section{Determination of mechanisms of antibiosis (bactericidal or bacteriostatic)}

The MBC is the lowest concentration of antimicrobial agents required to kill a particular bacterium. The mechanism of antibiosis of the soap samples was calculated using the ratio of MBC or MIC or MIC ${ }_{\text {index }}$ as described by Shanmughapriya et al. (2008) to elucidate whether the observed antibacterial effects were bactericidal or bacteriostatic. Although antimicrobials are usually regarded as bactericidal if the MBC is no more than four times the MIC (French 2006), when the ratio of $\mathrm{MBC}$ or $\mathrm{MIC}$ was $\leq 2.0$, the soap samples were considered bactericidal or otherwise bacteriostatic. If the ratio was $\geq 16.0$, the extract was considered ineffective.

\section{Statistical analysis}

All the data were subjected to one-way analysis of variance (ANOVA), and the mean values were separated at $p<0.05$ using Duncan's multiple range test. The one-way ANOVA test was used to determine if there was any statistically significant difference in the inhibition zones of each bacterial isolate produced by each soap sample. All statistical analyses were done using SPSS software (2009).

\section{Results}

The resulting zones of inhibition from the different soap samples were compared statistically and are presented in Table 1. From this study, the black soap samples from different sources were able to inhibit the growth of the test bacterial isolates in the different concentrations used. The antibacterial activities were concentration dependent in all the black soap samples except for those of the selected antibacterial medicated soaps that were slightly active at their highest concentrations. Comparatively, the statistical analysis of the inhibition zones showed that each black soap sample was significantly more active than each of the selected antibacterial soaps against the selected test bacterial strains. Although the antibacterial activities of OYN6, OYN7 and OYN8 were not significantly different from those of OYN3, OYN4 and OYN5, the antibacterial activities of most of the other black soaps were significantly different from each other. Although $66.67 \%$ of the samples compared exhibited significantly different antibacterial activities, $33.33 \%$ of the samples were not significantly different in their antibacterial activities. With the exception of OYN8, OYN9 OYN10 which produced inhibition zones equal to $20 \mathrm{~mm} \pm 1.0 \mathrm{~mm}$ in E. faecalis, $100 \mu \mathrm{L}$ of the highest concentration of $32 \mathrm{mg} / \mathrm{mL}$ of all the black soap samples produced inhibition zones greater than $20 \mathrm{~mm}$ $\pm 1.0 \mathrm{~mm}$ from all the other organisms. Although K. pneumoniae was the most susceptible to OYN1, OYN2, OYN3 and OYN4 samples, E. faecalis was the most susceptible to OYN2, OYN6 and OYN7, E. coli was the most susceptible to OYN9 and OYN10, and S. aureus and P. aeruginosa had their highest inhibition zone from OYN5. Although all the black soap samples were effective against the bacterial isolates at the different concentrations used, $100 \mu \mathrm{L}$ of $24 \mathrm{mg} / \mathrm{mL}$ of the antibacterial medicated soap samples was the only concentration effective against the bacterial isolates (Figure 1). The largest inhibition zones were obtained in the black soaps compared to the medicated antibacterial soaps showing no zone of inhibition at different concentrations.

To establish the degree of antibacterial activities of the different soap samples, their antibacterial activities were further investigated by macrobroth dilutions to determine the MIC and MBC. The resulting MIC and MBC are summarised in Figure 2. The MIC for K. pneumoniae and E. faecalis ranged between $0.125 \mathrm{mg} / \mathrm{mL}$ and $2 \mathrm{mg} / \mathrm{mL}$, for S. aureus ranged between $0.25 \mathrm{mg} / \mathrm{mL}$ and $4 \mathrm{mg} / \mathrm{mL}$, for $E$. coli ranged between $0.125 \mathrm{mg} / \mathrm{mL}$ and $4 \mathrm{mg} / \mathrm{mL}$ and for $P$. aeruginosa ranged between $1 \mathrm{mg} / \mathrm{mL}$ and $4 \mathrm{mg} / \mathrm{mL}$. The result showed that $K$. pneumoniae was the most susceptible, followed by E. faecalis $>$ E. coli $>$ S. aureus $>$ P. aeruginosa. The $\mathrm{MIC}_{\text {index }}$ indicating whether the antibacterial activities of the black soaps were bactericidal or bacteriostatic showed that the activities of the soap samples were mostly bactericidal. Although the MBCs were higher than the MICs, the differences in the MICs and MBCs showed the black soaps to have a selective antibacterial activity. That the MBCs were not more than four times the MICs in most cases and $\mathrm{MIC}_{\text {index }}$ was mostly equal to 2 showed that the black soap samples have bactericidal effects.

\section{Discussion}

In time past, the cosmetic, toiletry and pharmaceutical industry had a selection of fewer than 100 plant preparations from which to choose. However, prior to the advent of this industry, the ethnotherapeutic application of ethnomedicine by local people, including the use of African 
TABLE 1: Comparative analysis of the inhibition zones produced by the different soap samples.

\begin{tabular}{|c|c|c|c|c|c|c|c|c|c|c|}
\hline \multirow[t]{2}{*}{ Pair } & \multirow[t]{2}{*}{ Sample codes } & \multirow[t]{2}{*}{ Mean } & \multirow[t]{2}{*}{ Std. deviation } & \multirow[t]{2}{*}{ Std. error mean } & \multicolumn{2}{|c|}{$\begin{array}{l}95 \% \text { Confidence interval of } \\
\text { the difference }\end{array}$} & \multirow[t]{2}{*}{$t$} & \multirow[t]{2}{*}{ df } & \multirow[t]{2}{*}{$\begin{array}{l}\text { Sig (2-tailed) } \\
\quad P<0.05\end{array}$} & \multirow[t]{2}{*}{ Decision } \\
\hline & & & & & Lower & Upper & & & & \\
\hline Pair 1 & OYN1 - OYN2 & -3.16667 & 3.25982 & 0.59516 & -4.38390 & -1.94943 & -5.321 & 29 & 0.000 & Reject HO \\
\hline Pair 2 & OYN1 - OYN3 & -2.80000 & 3.06707 & 0.55997 & -3.94526 & -1.65474 & -5.000 & 29 & 0.000 & Reject $\mathrm{HO}$ \\
\hline Pair 3 & OYN1 - OYN4 & -2.46667 & 3.18112 & 0.58079 & -3.65452 & -1.27882 & -4.247 & 29 & 0.000 & Reject HO \\
\hline Pair 4 & OYN1 - OYN5 & -2.30000 & 3.36462 & 0.61429 & -3.55637 & -1.04363 & -3.744 & 29 & 0.001 & Reject HO \\
\hline Pair 5 & OYN1 - OYN6 & -2.00000 & 3.95666 & 0.72238 & -3.47744 & -0.52256 & -2.769 & 29 & 0.010 & Reject HO \\
\hline Pair 6 & OYN1 - OYN7 & -2.43333 & 3.24498 & 0.59245 & -3.64503 & -1.22164 & -4.107 & 29 & 0.000 & Reject HO \\
\hline Pair 7 & OYN1 - OYN8 & -1.80000 & 3.44814 & 0.62954 & -3.08756 & -0.51244 & -2.859 & 29 & 0.008 & Reject HO \\
\hline Pair 8 & OYN1 - OYN9 & -0.80000 & 3.08947 & 0.56406 & -1.95363 & 0.35363 & -1.418 & 29 & 0.167 & Accept $\mathrm{HO}$ \\
\hline Pair 9 & OYN1 - OYN10 & -1.30000 & 3.89651 & 0.71140 & -2.75498 & 0.15498 & -1.827 & 29 & 0.078 & Accept $\mathrm{HO}$ \\
\hline Pair 10 & OYN1 - OYN11 & 13.56667 & 5.76364 & 1.05229 & 11.41449 & 15.71885 & 12.892 & 29 & 0.000 & Reject HO \\
\hline Pair 11 & OYN1 - OYN12 & 12.73333 & 5.97658 & 1.09117 & 10.50164 & 14.96503 & 11.669 & 29 & 0.000 & Reject HO \\
\hline Pair 12 & OYN1 - OYN13 & 12.10000 & 6.60381 & 1.20569 & 9.63410 & 14.56590 & 10.036 & 29 & 0.000 & Reject HO \\
\hline Pair 13 & OYN2 - OYN3 & 0.36667 & 2.14127 & 0.39094 & -0.43290 & 1.16623 & 0.938 & 29 & 0.356 & Accept $\mathrm{HO}$ \\
\hline Pair 14 & OYN2 - OYN4 & 0.70000 & 1.85974 & 0.33954 & 0.00556 & 1.39444 & 2.062 & 29 & 0.048 & Reject HO \\
\hline Pair 15 & OYN2 - OYN5 & 0.86667 & 1.90703 & 0.34818 & 0.15457 & 1.57877 & 2.489 & 29 & 0.019 & Reject HO \\
\hline Pair 16 & OYN2 - OYN6 & 1.16667 & 2.85371 & 0.52101 & 0.10107 & 2.23226 & 2.239 & 29 & 0.033 & Reject $\mathrm{HO}$ \\
\hline Pair 17 & OYN2 - OYN7 & 0.73333 & 2.01603 & 0.36807 & -0.01946 & 1.48613 & 1.992 & 29 & 0.056 & Accept HO \\
\hline Pair 18 & OYN2 - OYN8 & 1.36667 & 2.79758 & 0.51077 & 0.32203 & 2.41130 & 2.676 & 29 & 0.012 & Reject HO \\
\hline Pair 19 & OYN2 - OYN9 & 2.36667 & 3.60539 & 0.65825 & 1.02039 & 3.71294 & 3.595 & 29 & 0.001 & Reject HO \\
\hline Pair 20 & OYN2 - OYN10 & 1.86667 & 3.52071 & 0.64279 & 0.55201 & 3.18132 & 2.904 & 29 & 0.007 & Reject HO \\
\hline Pair 21 & OYN2 - OYN11 & 16.73333 & 4.74838 & 0.86693 & 14.96026 & 18.50641 & 19.302 & 29 & 0.000 & Reject HO \\
\hline Pair 22 & OYN2 - OYN12 & 15.90000 & 5.26111 & 0.96054 & 13.93547 & 17.86453 & 16.553 & 29 & 0.000 & Reject HO \\
\hline Pair 23 & OYN2 - OYN13 & 15.26667 & 6.00536 & 1.09642 & 13.02423 & 17.50911 & 13.924 & 29 & 0.000 & Reject HO \\
\hline Pair 24 & OYN3 - OYN4 & 0.33333 & 1.44636 & 0.26407 & -0.20675 & 0.87341 & 1.262 & 29 & 0.217 & Accept HO \\
\hline Pair 25 & OYN3 - OYN5 & 0.50000 & 1.73702 & 0.31714 & -0.14861 & 1.14861 & 1.577 & 29 & 0.126 & Accept HO \\
\hline Pair 26 & OYN3 - OYN6 & 0.80000 & 2.05779 & 0.37570 & 0.03161 & 1.56839 & 2.129 & 29 & 0.042 & Reject HO \\
\hline Pair 27 & OYN3 - OYN7 & 0.36667 & 2.09241 & 0.38202 & -0.41465 & 1.14798 & 0.960 & 29 & 0.345 & Accept HO \\
\hline Pair 28 & OYN3 - OYN8 & 1.00000 & 1.66091 & 0.30324 & 0.37981 & 1.62019 & 3.298 & 29 & 0.003 & Reject HO \\
\hline Pair 29 & OYN3 - OYN9 & 2.00000 & 2.82843 & 0.51640 & 0.94385 & 3.05615 & 3.873 & 29 & 0.001 & Reject HO \\
\hline Pair 30 & OYN3 - OYN10 & 1.50000 & 1.99569 & 0.36436 & 0.75480 & 2.24520 & 4.117 & 29 & 0.000 & Reject HO \\
\hline Pair 31 & OYN3 - OYN11 & 16.36667 & 4.52947 & 0.82696 & 14.67534 & 18.05800 & 19.791 & 29 & 0.000 & Reject HO \\
\hline Pair 32 & OYN3 - OYN12 & 15.53333 & 4.87593 & 0.89022 & 13.71263 & 17.35404 & 17.449 & 29 & 0.000 & Reject $\mathrm{HO}$ \\
\hline Pair 33 & OYN3 - OYN13 & 14.90000 & 5.42249 & 0.99001 & 12.87521 & 16.92479 & 15.050 & 29 & 0.000 & Reject HO \\
\hline Pair 34 & OYN4 - OYN5 & 0.16667 & 1.59921 & 0.29197 & -0.43049 & 0.76382 & 0.571 & 29 & 0.573 & Accept HO \\
\hline Pair 35 & OYN4 - OYN6 & 0.46667 & 2.04658 & 0.37365 & -0.29754 & 1.23087 & 1.249 & 29 & 0.222 & Accept HO \\
\hline Pair 36 & OYN4 - OYN7 & 0.03333 & 1.47352 & 0.26903 & -0.51689 & 0.58356 & 0.124 & 29 & 0.902 & Accept $\mathrm{HO}$ \\
\hline Pair 37 & OYN4 - OYN8 & 0.66667 & 1.78757 & 0.32636 & -0.00082 & 1.33416 & 2.043 & 29 & 0.050 & Accept HO \\
\hline Pair 38 & OYN4 - OYN9 & 1.66667 & 2.53708 & 0.46321 & 0.71930 & 2.61403 & 3.598 & 29 & 0.001 & Reject HO \\
\hline Pair 39 & OYN4 - OYN10 & 1.16667 & 2.18274 & 0.39851 & 0.35162 & 1.98172 & 2.928 & 29 & 0.007 & Reject HO \\
\hline Pair 40 & OYN4 - OYN11 & 16.03333 & 4.49891 & 0.82139 & 14.35341 & 17.71326 & 19.520 & 29 & 0.000 & Reject HO \\
\hline Pair 41 & OYN4 - OYN12 & 15.20000 & 4.80230 & 0.87678 & 13.40679 & 16.99321 & 17.336 & 29 & 0.000 & Reject HO \\
\hline Pair 42 & OYN4 - OYN13 & 14.56667 & 5.55650 & 1.01447 & 12.49183 & 16.64150 & 14.359 & 29 & 0.000 & Reject HO \\
\hline Pair 43 & OYN5 - OYN6 & 0.30000 & 1.95024 & 0.35606 & -0.42823 & 1.02823 & 0.843 & 29 & 0.406 & Accept HO \\
\hline Pair 44 & OYN5 - OYN7 & -0.13333 & 1.52527 & 0.27847 & -0.70288 & 0.43621 & -0.479 & 29 & 0.636 & Accept $\mathrm{HO}$ \\
\hline Pair 45 & OYN5 - OYN8 & 0.50000 & 1.73702 & 0.31714 & -0.14861 & 1.14861 & 1.577 & 29 & 0.126 & Accept $\mathrm{HO}$ \\
\hline Pair 46 & OYN5 - OYN9 & 1.50000 & 3.14862 & 0.57486 & 0.32429 & 2.67571 & 2.609 & 29 & 0.014 & Reject HO \\
\hline Pair 47 & OYN5 - OYN10 & 1.00000 & 2.84059 & 0.51862 & -0.06069 & 2.06069 & 1.928 & 29 & 0.064 & Accept $\mathrm{HO}$ \\
\hline Pair 48 & OYN5 - OYN11 & 15.86667 & 4.81186 & 0.87852 & 14.06989 & 17.66345 & 18.061 & 29 & 0.000 & Reject $\mathrm{HO}$ \\
\hline Pair 49 & OYN5 - OYN12 & 15.03333 & 5.14938 & 0.94014 & 13.11052 & 16.95614 & 15.990 & 29 & 0.000 & Reject HO \\
\hline Pair 50 & OYN5 - OYN13 & 14.40000 & 5.63609 & 1.02900 & 12.29545 & 16.50455 & 13.994 & 29 & 0.000 & Reject HO \\
\hline Pair 51 & OYN6 - OYN7 & -0.43333 & 1.50134 & 0.27411 & -0.99394 & 0.12728 & -1.581 & 29 & 0.125 & Accept HO \\
\hline Pair 52 & OYN6 - OYN8 & 0.20000 & 2.49689 & 0.45587 & -0.73236 & 1.13236 & 0.439 & 29 & 0.664 & Accept HO \\
\hline Pair 53 & OYN6 - OYN9 & 1.20000 & 3.61415 & 0.65985 & -0.14955 & 2.54955 & 1.819 & 29 & 0.079 & Accept HO \\
\hline Pair 54 & OYN6 - OYN10 & 0.70000 & 2.87858 & 0.52555 & -0.37488 & 1.77488 & 1.332 & 29 & 0.193 & Accept HO \\
\hline Pair 55 & OYN6 - OYN11 & 15.56667 & 4.94580 & 0.90298 & 13.71988 & 17.41346 & 17.239 & 29 & 0.000 & Reject HO \\
\hline Pair 56 & OYN6 - OYN12 & 14.73333 & 5.00988 & 0.91467 & 12.86262 & 16.60405 & 16.108 & 29 & 0.000 & Reject HO \\
\hline Pair 57 & OYN6 - OYN13 & 14.10000 & 5.13507 & 0.93753 & 12.18253 & 16.01747 & 15.039 & 29 & 0.000 & Reject HO \\
\hline Pair 58 & OYN7 - OYN8 & 0.63333 & 2.41380 & 0.44070 & -0.26799 & 1.53466 & 1.437 & 29 & 0.161 & Accept $\mathrm{HO}$ \\
\hline Pair 59 & OYN7 - OYN9 & 1.63333 & 3.22152 & 0.58817 & 0.43040 & 2.83627 & 2.777 & 29 & 0.010 & Reject $\mathrm{HO}$ \\
\hline
\end{tabular}


TABLE 1 (Continues...): Comparative analysis of the inhibition zones produced by the different soap samples.

\begin{tabular}{|c|c|c|c|c|c|c|c|c|c|c|}
\hline \multirow[t]{2}{*}{ Pair } & \multirow[t]{2}{*}{ Sample codes } & \multirow[t]{2}{*}{ Mean } & \multirow[t]{2}{*}{ Std. deviation } & \multirow[t]{2}{*}{ Std. error mean } & \multicolumn{2}{|c|}{$\begin{array}{l}95 \% \text { Confidence interval of } \\
\text { the difference }\end{array}$} & \multirow[t]{2}{*}{$t$} & \multirow[t]{2}{*}{ df } & \multirow[t]{2}{*}{$\begin{array}{l}\text { Sig (2-tailed) } \\
\quad P<0.05\end{array}$} & \multirow[t]{2}{*}{ Decision } \\
\hline & & & & & Lower & Upper & & & & \\
\hline Pair 60 & OYN7 - OYN10 & 1.13333 & 3.10432 & 0.56677 & -0.02584 & 2.29250 & 2.000 & 29 & 0.055 & Accept HO \\
\hline Pair 61 & OYN7 - OYN11 & 16.00000 & 4.86366 & 0.88798 & 14.18388 & 17.81612 & 18.018 & 29 & 0.000 & Reject HO \\
\hline Pair 62 & OYN7 - OYN12 & 15.16667 & 5.01778 & 0.91612 & 13.29300 & 17.04034 & 16.555 & 29 & 0.000 & Reject HO \\
\hline Pair 63 & OYN7 - OYN13 & 14.53333 & 5.55681 & 1.01453 & 12.45839 & 16.60828 & 14.325 & 29 & 0.000 & Reject HO \\
\hline Pair 64 & OYN8 - OYN9 & 1.00000 & 2.50517 & 0.45738 & 0.06456 & 1.93544 & 2.186 & 29 & 0.037 & Reject HO \\
\hline Pair 65 & OYN8 - OYN10 & 0.50000 & 1.73702 & 0.31714 & -0.14861 & 1.14861 & 1.577 & 29 & 0.126 & Accept HO \\
\hline Pair 66 & OYN8 - OYN11 & 15.36667 & 4.54467 & 0.82974 & 13.66966 & 17.06367 & 18.520 & 29 & 0.000 & Reject HO \\
\hline Pair 67 & OYN8 - OYN12 & 14.53333 & 5.00161 & 0.91316 & 12.66570 & 16.40096 & 15.915 & 29 & 0.000 & Reject HO \\
\hline Pair 68 & OYN8 - OYN13 & 13.90000 & 5.73164 & 1.04645 & 11.75977 & 16.04023 & 13.283 & 29 & 0.000 & Reject HO \\
\hline Pair 69 & OYN9 - OYN10 & -0.50000 & 2.51547 & 0.45926 & -1.43929 & 0.43929 & -1.089 & 29 & 0.285 & Accept $\mathrm{HO}$ \\
\hline Pair 70 & OYN9 - OYN11 & 14.36667 & 5.18940 & 0.94745 & 12.42891 & 16.30442 & 15.163 & 29 & 0.000 & Reject HO \\
\hline Pair 71 & OYN9 - OYN12 & 13.53333 & 5.52570 & 1.00885 & 11.47000 & 15.59666 & 13.415 & 29 & 0.000 & Reject HO \\
\hline Pair 73 & OYN10 - OYN11 & 14.86667 & 4.55414 & 0.83147 & 13.16612 & 16.56721 & 17.880 & 29 & 0.000 & Reject HO \\
\hline Pair 74 & OYN10 - OYN12 & 14.03333 & 5.16943 & 0.94380 & 12.10304 & 15.96363 & 14.869 & 29 & 0.000 & Reject HO \\
\hline Pair 75 & OYN10 - OYN13 & 13.40000 & 5.88745 & 1.07490 & 11.20159 & 15.59841 & 12.466 & 29 & 0.000 & Reject HO \\
\hline Pair 76 & OYN11 - OYN12 & -0.83333 & 4.19428 & 0.76577 & -2.39950 & 0.73284 & -1.088 & 29 & 0.285 & Accept HO \\
\hline Pair 77 & OYN11 - OYN13 & -1.46667 & 5.41857 & 0.98929 & -3.48999 & 0.55666 & -1.483 & 29 & 0.149 & Accept HO \\
\hline Pair 78 & OYN12 - OYN13 & -0.63333 & 3.29559 & 0.60169 & -1.86393 & 0.59726 & -1.053 & 29 & 0.301 & Accept HO \\
\hline
\end{tabular}

$\mathrm{HO}$, there are no significant differences in the antibacterial activities of the different soaps $(p<0.05)$;

OYN1 - OYN10, Different black soap samples; OYN11 - OYN13, Different medicated antibacterial soaps; $t$, $t$-test; $\mathrm{df}$, degree of freedom.

black soap in some parts of Africa, has been in practice indigenously. Today, the number of plant materials being used, either alone or in combinations, in ethnomedicine is in the hundreds, and the new discoveries are becoming more and more exotic of each day, at the expense of the medicinal potential invested in African black soap. Mere handling of African black soap by some people is considered a taboo because of its use by the traditional healers, civilisation and modernisation, whereas a skin infection that could have been healed by using cheap and effective African black soap with great medicinal potential is allowed to aggravate and become a chronic, contagious and long-term infection.

In this study, the medicinal potential of African black soap with respect to its advantage over some commonly sold antibacterial medicated soap is elucidated. All the black soaps exhibited varied degrees of inhibitory effects against the growth of different bacterial strains. It revealed that the antibacterial effect of African black soap on $S$. aureus, E. coli, P. aeruginosa, K. pneumoniae and E. faecalis was significantly higher $(p>0.05)$ than those of the antibacterial medicated soaps. Although their antibacterial effects were concentration dependent and effective at very low MICs ranging between $0.125 \mathrm{mg} / \mathrm{mL}$ and $4 \mathrm{mg} / \mathrm{mL}$, those of the medicated soaps were significantly higher. The susceptibilities of these organisms to the different black soaps indicated their therapeutic potentials in the treatment of wound and skin infection in which they might be involved and justified their use in ethnomedical practices.

Although this study is in agreement with the report of Popoola (2005), their antibacterial activities compared with those of antibacterial medicated soap are rare. Although the active ingredients in medicated soap are known and are often rich in glycerine, detergents, isopropylalcohol and some chemicals capable of causing irritation on dry and sensitive skin types (Omobuwajo et al. 2011), the antibacterial potential of African black soap may be attributed to the synergy between the phytochemicals in the plants and oils serving as components of the black soaps. These phytochemicals may include bioactive compounds such as alkaloids, flavonoids, pigments, phenolics, terpenoids, steroids and essential oils (Rajeshkumar et al. 2002). The palm kernel oil contains dodecanoic acid (Collin \& Hilditch 1928), whereas the palm oil contains saturated palmitic, oleic and linoleic acid (Duke 1983). The shea butter is composed of five principal fatty acids, palmitic, stearic, oleic, linoleic and arachidic acid, with stearic and oleic acids accounting for $85 \%-90 \%$ of its fatty acid (Maranz et al. 2004). Although the fatty acids and their derivatives in the oil used can have adverse effects on different bacteria (Kabara 1978) and act as anionic surfactants, targeting the structure and function of bacterial cell wall and membranes, with antibacterial activity at low pH (Hayes \& Berkovitz 1979), fatty acids such as stearic and palmitic acid and hydroxyl fatty esters such as hydroxyl esters of stearic, plamitic and myristic acids also possess antibacterial properties (Bhattacharya et al. 2007; Liao et al. 1999). Although palm kernel oil has phenolic compounds known to have antimicrobial activities (Steven et al. 2003), its lauric acid has also been considered to have antibacterial properties (Ugbogu 2006). These soaps, to a large extent, remove dirt and disrupt cytoplasmic membrane to kill microorganisms (Tachibana 1976) and inhibit fatty acid synthesis by binding to bacterial enoyl-acyl carrier protein reductase enzyme (McMurry et al. 1998). Although the long chain fatty acids may have disrupted bacterial membrane integrity leading to leakage of macromolecules such as 


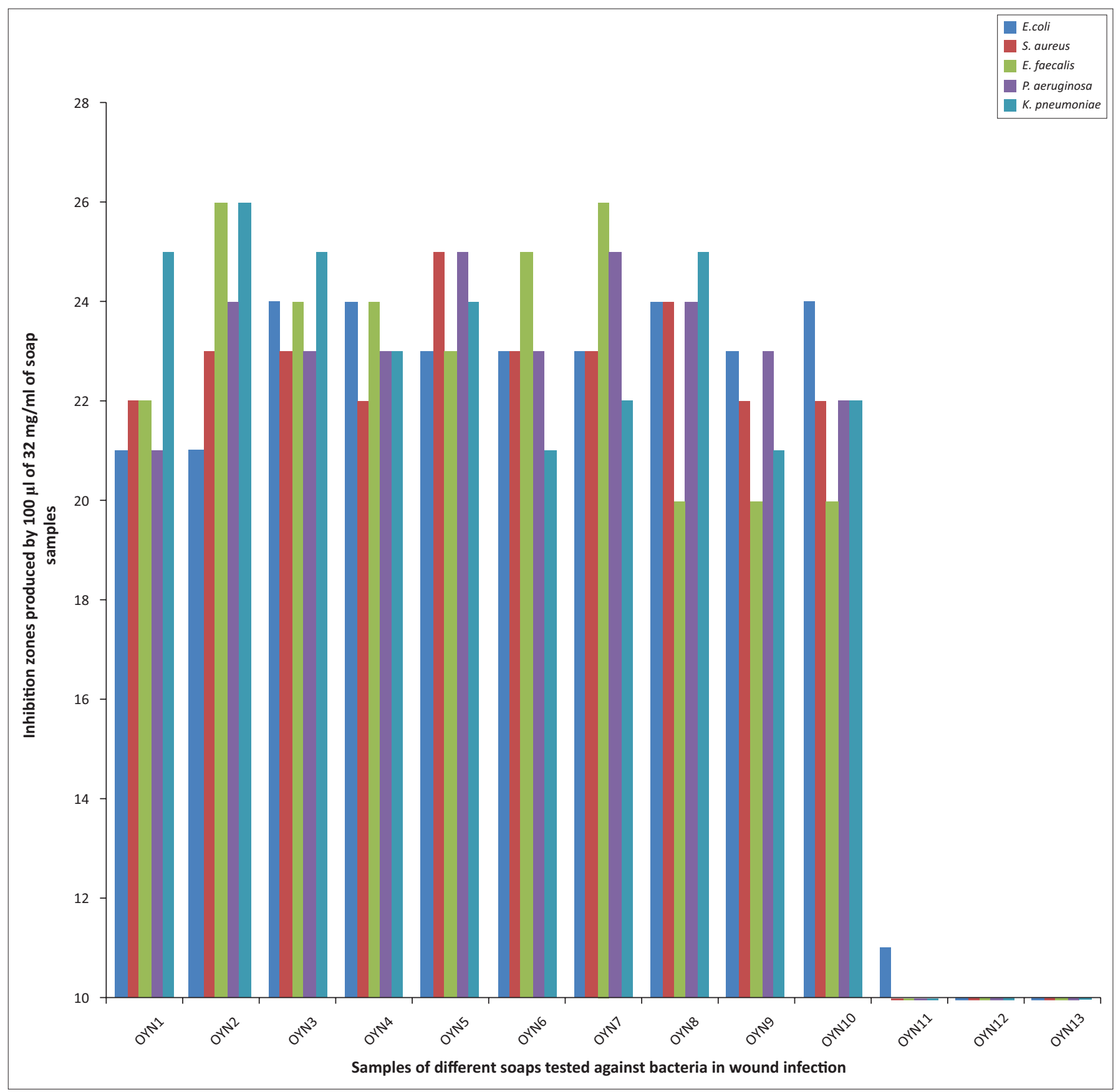

FIGURE 1: Susceptibility of bacterial isolates to $100 \mu \mathrm{L}$ of $32 \mathrm{mg} / \mathrm{mL}$ of different soap samples.

nucleotide, inorganic acids or phosphorylated ammonium compounds (Arora 2010), Desbois and Smith (2010) reported that free fatty acids are capable of inhibiting the bacterial electron transport chain, oxidative phosphorylation, enzyme activity, impairment of nutrient uptake, generation of peroxidation and auto-oxidation degradation products or direct lysis of bacterial cells. Hence, the antibacterial activity of the African black soaps may have been because of the proportion of the fatty acid portions and the phytoconstituents in the plants used.

Considering the materials required in its production, it may be concluded that the production of African black soap is, simply, a conversion of waste to wealth. The black soap is made from the ashes of plantain skin, cocoa pod, palm leaves and palm oil from kernels. Harvesting these wastes for massive production of black soap would be of economic significance. Eroding the notion that the use of black soap is fetish would promote the image, and its general acceptability will put the soap in high demand. This would bring about economic turn-around in the parts of Africa where it is being produced. Improving its packaging and the addition of pharmaceuticals relevant in cosmetic pharmacy will, also, put the African black soap on high marketable pedestals with medicated soaps globally accepted. Black soap is a monumental economic product from waste materials which must be tapped for global economic development especially in Africa. 


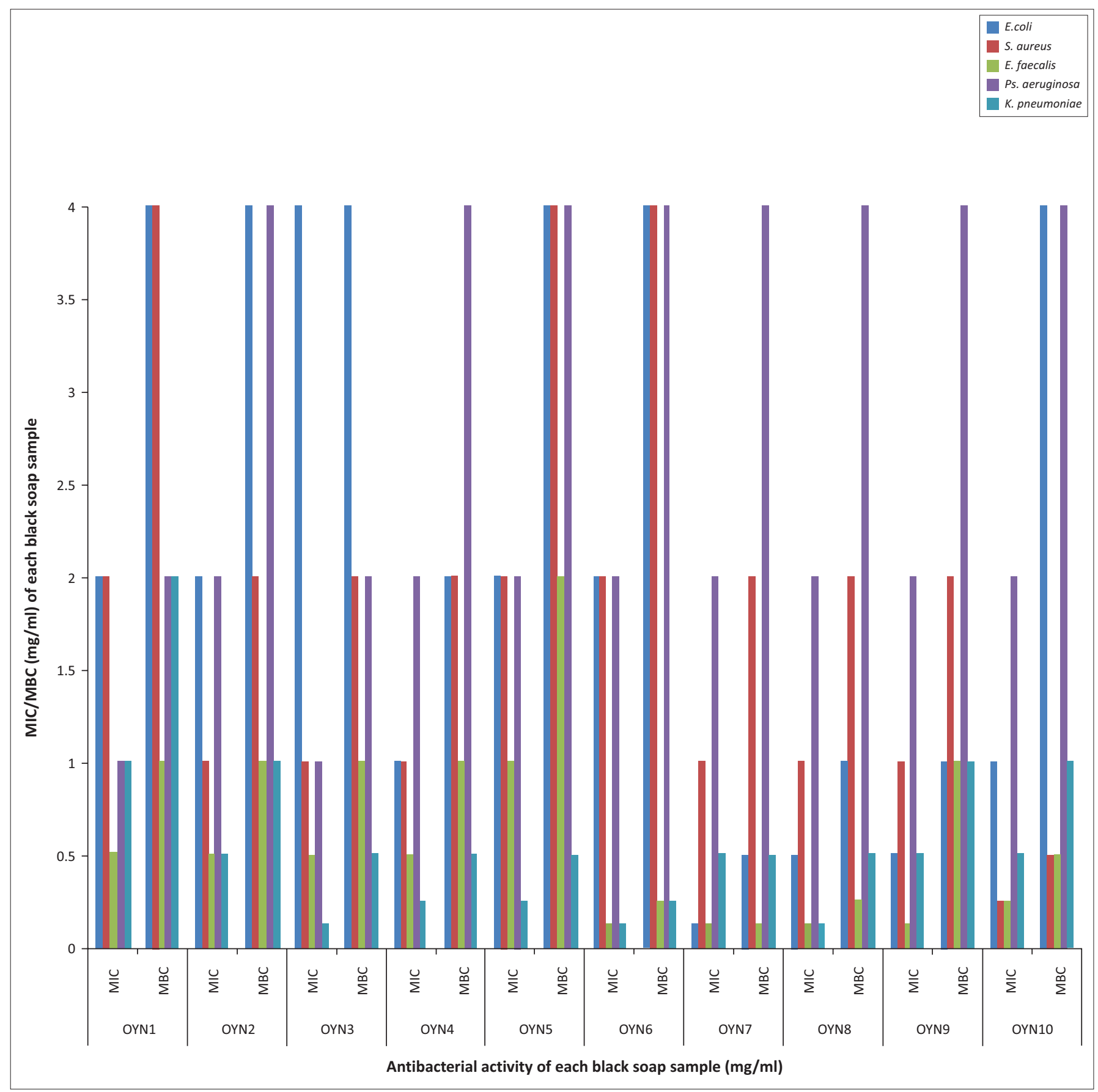

FIGURE 2: Composite bar chart showing the minimum inhibitory concentration and minimum bactericidal concentration of the different African black soaps.

In conclusion, because antibacterial activity is the ability to either destroy bacteria or inhibit their growth and soaps have been known to play important roles in killing bacteria and treating dermatitis and psoriasis, the African black soaps in this study showed significant antibacterial activity greater than those of the medicated soaps and justified their ethnomedicinal use in the treatment of skin infections. The study, therefore, signifies the ethnomedicinal importance of African black soaps as having a great potential in restraining the growth of multidrug resistant infectious microorganisms and can be a better option in place of commercially available antibacterial medicated and antiseptic soaps. Its cost of production is low compared to the amount of wealth that could be generated if it is globally accepted.

\section{Acknowledgements Competing interests}

The authors declare that they have no financial or personal relationships which may have inappropriately influenced them in writing this article.

\section{Authors' contributions}

All authors contributed equally to the conception, generation of data, data analysis and writing up and agreed together to the submission of the manuscript to this journal. 


\section{References}

Adebiyi, M.A., 1980, 'A study of chemical, physical and antibacterial properties of Nigerian soft soaps (Ose Dudu)', M.Phil. thesis, University of Ife, Ile-Ife, Nigeria.

Adelakun, N., 1990, 'Want to look beautiful, black soap will do the trick', Todays Choice Publication Nigeria 1(5), 14.

Ahmed, O.A., Odunukwe, N.N., Akinwale, O.P., Raheem, T.Y., Efienemokwu, C.E., Ogedengbe, $\mathrm{O}$. et al., 2005, 'Knowledge and practices of traditional birth attendants in prenatal services in Lagos State, Nigeria', African Journal of Medicine and Medical Sciences 34(1), 55-58.

Ajaiyeoba, E.O., Oladepo, O., Fawole, O.I., Bolaji, O.M., Akinboye, D.O., Ogundahunsi, O.A. et al., 2003, 'Cultural categorization of febrile illnesses in correlation with herbal remedies used for treatment in Southwestern Nigeria', Journal of Ethnopharmacology 85(2-3), 179-185. https://doi.org/10.1016/S0378-8741(02)00357-4

Ajose, F.O., 2007, 'Some Nigerian plants of dermatologic importance', International Journal of Dermatology 46(Suppl 1), 48-55. https://doi.org/10.1111/j.1365-4632. 2007.03466.x

Aliyu, M.S., Tijjani, M.B., Doko, M.H.I., Garba, I., Ibrahim, M.M., Abdulkadir, S.M. et al., 2012, 'Antimicrobial activity of Sabulun Salo a local traditional medicated Soap', Nigerian Journal of Basic and Applied Sciences 20(1), 35-38.

Arora, 2004, Textbook of microbiology, Satish Kumar Publishers, New Delhi, India.

Arya, M., Arya, P., Biswas, D. \& Prasad, R., 1966, 'Antimicrobial susceptibility pattern of bacterial isolates from post-operative wound infections', Indian Journal of Pathology and Microbiology 48(2), 266-269.

Bauer, A.W., Kirby, W.M., Sherris, J.C. \& Truck, M., 1966, 'Antibiotic susceptibility testing by a standardized single disk method', American Journal of Clinical Pathology 45, 493-496.

Bella, O., 2011, African black soap, viewed 16 July 2013, from http://www.bellaonline. com/article/art26546.asp

Bhattacharya, S., Mula, S., Gamre, S., Kamat, J.P., Bandyopadhyay, S.K. \& Chattopadhyay, S., 2007, 'Inhibitory property of Piper betel extract against photosensitization-induced damages to lipids and proteins', Food Chemistry 100 1474-1480. https://doi.org/10.1016/j.foodchem.2005.12.041

British Society for Antimicrobial Chemotherapy (BSAC), 2013, Methods for antimicrobial susceptibility testing, viewed 6 November 2013, from http://bsac. org.uk/wp-content/uploads/2012/02/Version-11.1-2012-Final-.pdf

Cheesbrough, M., 2002, Medical laboratory manual for tropical countries, vol. 2, ELBS, Tropical Health Technology Publications and Butterworth-Heinemann, Cambridge, UK.

Cheesbrough, M., 2006, District laboratory practice in tropical countries, 1st edn., Cambridge University Press, Cambridge, UK, p. 434

Clinical and Laboratory Standards Institute (CLSI), 2002, Performance standards for antimicrobial disk and dilution susceptibility tests for bacteria isolated from animals, Approved Standard M31-A2:1-80, NCCLS, Wayne, PA.

Clinical and Laboratory Standard Institute (CLSI), 2015, M100-S25: Performance standards for antimicrobial susceptibility testing: twenty-fifth informational supplement, vol. 35 , no. 3 , pp. 240.

Collin, G. \& Hilditch, T.P., 1928, 'The component glycerides of coconut and palm Kerne fats', Journal of the Chemical Society, Transactions 47, 261-269.

Considine, D.M., ed., 1974, 'Soap', in D.M. Cosidine (ed.), 'Chemical and Process Technology Encyclopedia', McGraw-Hill Books Company, New York, pp. 1045-1049.

Desbois, A.P. \& Smith, V.J., 2010, 'Antibacterial free fatty acids: Activities mechanisms of action and biotechnological potential', Applied Microbiology and Biotechnology 85(6), 1629-1642. https://doi.org/10.1007/s00253-009-2355-3

Duke, A.J., 1983, Handbook of energy crops, Unpublished, pp. 1-5.

European Committee for Antimicrobial Susceptibility Testing (EUCAST), 2000, 'Determination of minimum inhibitory concentrations (MICs) of antibacteria doi.org/10.1046/j.1469-0691.2000.00142.x

French, G.L., 2009, 'Bactericidal agents in the treatment of MRSA infections - The gastrointestinal tract protects germ-free mice against Salmonella typhimurium infection', Gut 49(1), 47-55.

Friedman, M. \& Wolf, R., 1996, 'Chemistry of soaps and detergents: Various types of commercial products and their ingredients', Clinics in Dermatology 14(1), 7-13. https://doi.org/10.1016/0738-081X(95)00102-L

Fuls, J.L., Rodgers, N.D., Fischler, G.E., Howard, J.M., Patel, M., Weidner, P.L. et al., 2008 , 'Alternative hand contamination technique to compare the activities of antimicrobial and non-antimicrobial soaps under different test conditions', Journal of Applied \& Environmental Microbiology 74(12), 3739-3744. https://doi. org/10.1128/AEM.02405-07

Getradeghana, B.T., 2000, 'Evaluation of African traditional soap', Global Journal of Pure and Applied Sciences 6, 174-179.

Grayson, M., 1983, 'Soap', in Encyclopedia of chemical technology, 3rd edn., vol. 21, pp. 369-406, Wiley-Interscience Publications, New York.

Grieve, M., 1997, Modern herbal medicine, 1st edn., Saunders Company Limited, London, pp. 64-74.
Hayes, M.L. \& Berkovitz, B.K., 1979, 'The reduction of fissure caries in Wistar rats by a soluble salt of nonanionic acid', Archives of Oral Biology 24, 663-666. https://doi. org/10.1016/0003-9969(79)90115-8

Irkin, R. \& Korukluoglu M., 2007, 'Control of Aspergillus niger with garlic, onion and leek extracts', African Journal of Biotechnology 6, 384-387.

Kabara, J.J., 1978, 'Health oils from the tree of life, in pharmacological effects of lipids. Kernels', Journal of Agricultural and Food Chemistry 51, 6268-6278.

Kubmarawa, D. \& Atiko, R., 2000, 'Production of soap from locally sourced caustic alkaline and oils', Journal of Chemical Society of Nigeria 25, 76.

Kuehl, B.L., Fyfe, K.S. \& Shear, N.H., 2003, 'Cutaneous cleansers', in Skin Therapy Letter 8(3), pp 1-4.

Lamikanra, A. \& Allwood, M.E., 1977, 'Effects of polyethoxyalkyl phenols on the leakage of intracellular materials from Staphylococcus aureus', Journal of Applied Microbiology 42, 379-385. https://doi.org/10.1111/j.1365-2672.1977. tb00705.x

Larson, E., Eke, P.I., Wilder, M.P. \& Laughon, B.E., 1987, 'Quantity of soap as a variable in hand washing', Infection Control 8, 371-375. https://doi.org/10.1017/ S0195941700067436

Liao, Y.L., Chiang, Y.C., Tsai, T.F., Lee, R.F., Chan, Y.C. \& Hsiao, C.H., 1999, 'Contact leukomelanosis induced by the leaves of Piper betle L. (Piperaceae): A clinical and histopathologic survey', Journal of The American Academy of Dermatology 40, 583-589. https://doi.org/10.1016/S0190-9622(99)70441-X

Maranz, S.Z., Wiesman, J. \& Bianchi, G., 2004, 'Germplasm resources of Vitellaria paradoxa based on variations in fat composition across the species distribution range', Agroforestry Systems 60, 71-76. https://doi.org/10.1023/B:AGFO. 0000009406.19593 .90

McMurry, L.M., Oethinger, M. \& Levy, S.B., 1998, 'Triclosan targets lipid synthesis', Nature 394, 531-532. https://doi.org/10.1038/28970

Moody, J.O., Adebiyi, O.A. \& Adeniyi, B.A., 2004, 'Do Aloe vera and Ageratum conyzoides enhance the anti-microbial activity of traditional medicinal soft soaps (Osedudu)?', Journal of Ethnopharmacology 92(1), 57-60. https://doi.org/ 10.1016/j.jep.2004.01.018

Omobuwajo, O.R., Abdu, A., Igbeneghu, O.A., Agboola, I.O. \& Alade, G.O., 2011 'Preliminary investigation of an herbal soap incorporating Cassia senna (L.) Roxby Leaves and Ageratum conyzoides Linn. whole plant powders', Continental Journal of Pharmaceutical Sciences 5, 1-10.

Osborne, R.C. \& Grube, J., 1982, 'Hand disinfection in dental practice', Journal of Clinical Preventive Dentistry 4(6), 11-15.

Popoola, L., 2005, 'Poverty and economic viability of neem tree growing in Nigeria', A Seminar presented at a workshop organized by Central Bank of Nigeria, Katsina State, Nigeria, 17th and 18th August.

Rajeshkumar, N.V., Joy, K.L., Kuttan, G., Ramsewak, R.S., Nair, M.G. \& Kuttan, R., 2002, 'Antitumor and anticarcinogenic activity of Phyllanthus amarus extract', Journal of Ethnopharmacology 81(1), 17-22. https://doi.org/10.1016/S0378-8741(01)00419-6

Schwartz, A.M., 1979, 'Detergents', in Encyclopaedia, Americana International edition, Grolier Incorporated, vol. 9, p. 21.

Shanmughapriya, S.A., Manilal, A., Sujith, S., Selvin, J., Kiran, G.S. \& Natarajaseenivasan K., 2008, 'Antimicrobial activity of seaweeds extracts against multi-resistant pathogens', Annals of Microbiology 58, 535-541. https://doi.org/10.1007/ BF03175554

Sharma, B.K., 2006, Industrial chemistry, 15th edn., GOEL Publishing House, Meerut-250 001 (U.P). pp. 1243-1245, 1249.

Sofowora, A., 1982, Medical plants and traditional medicine in Africa, 1st edn., Wiley, pp. 68-69.

Steven, M., Zeev, W. \& Nissim, G., 2003, 'Phenolic constituents of Shea (Vittellaria) Kernels', Journal of Agricultural and Food Chemistry 51, 6268-6278. https://doi. org/10.1021/jf034687t

Summers, G., 2016, African Black Soap: A recipe passed down for generations, viewed 10 January 2017, from https://www.liveabout.com/african-blacksoap- 2442627

Tachibana, D.K., 1976, 'Microbiology of the foot', Annual Review of Microbiology 30 350-375. https://doi.org/10.1146/annurev.mi.30.100176.002031

Toshima, Y., Ojima, M., Yamada, H., Mori, H., Tonomura, M., Hioki, Y. et al., 2001, 'Observation of everyday hand-washing behavior of Japanese, and effect of antibacterial soap', International Journal of Food Microbiology 68(1-2), 83-91. https://doi.org/10.1016/S0168-1605(01)00481-0

Ugbogu, O.C., 2006, 'Lauric acid content and inhibitory effect of palm kernel oil on two bacterial isolates and C. Albicans', African Journal of Biotechnology 5(11), 1045-1047

Ukatta, H.C., 1991, 'Determination of the susceptibility of Candida albicans and Staphylococcus aureus to Kaduna black soap sample', Science Africa 2, 26-30.

Underwood, 2008, What is black soap? viewed 15 January 2017, from https://www. treehugger.com/style/what-is-black-soap.html

Wiegand, I., Hilpert, K. \& Hancock, R.E.W., 2008, 'Agar and broth microdilution methods to determine the minimal inhibitory concentration (MIC) of antimicrobial substances', Nature Protocols 3, 163-175. https://doi.org/10.1038/nprot. 2007.521 